CCC 2019

Proceedings of the Creative Construction Conference (2019) 043

Edited by: Miroslaw J. Skibniewski \& Miklos Hajdu

https://doi.org/10.3311/CCC2019-043

Creative Construction Conference 2019, CCC 2019, 29 June - 2 July 2019, Budapest, Hungary

\title{
Emergent subcontracting models and owner involvement in selecting subcontracting strategies and participants in the U.S. construction industry
}

\author{
Luis R. Fernandez ${ }^{\mathrm{a}}$, Giovanni C. Migliaccio ${ }^{\mathrm{a}}$, Richard J. Gebken ${ }^{\mathrm{b}}$ \\ ${ }^{a}$ University of Washington, 120 Architecture Hall, Seattle, WA, 98105, USA \\ ${ }^{b}$ Missouri State University, 901 South National Avenue, Springfield, MO, 65897, USA
}

\begin{abstract}
Prime contracting models for a wide variety of Project Delivery Methods (PDM) have been described with great detail in the practice-oriented and academic literature. However, the same depth of understanding about contractual relationships between general and specialty contractors is less known, especially as specialty contractors are being increasingly involved in earlier project phases. The objective of this research is to describe subcontracting models, owner involvement scenarios, and their variations across the United States. Results of a nationwide survey and follow-up semi-structured interviews with industry practitioners indicate many subcontracting models are currently in use and that project owner involvement is widely variable. Presentation attendees should expect to gain a greater understanding of each of the identified subcontracting models as well as to learn the advantages, disadvantages, regional variations, and owner involvement under each.

(C) 2019 The Authors. Published by Budapest University of Technology and Economics \& Diamond Congress Ltd.

Peer-review under responsibility of the scientific committee of the Creative Construction Conference 2019.

Keywords: subcontracting model; nationwide; variations.
\end{abstract}

\section{Introduction}

Subcontracting practices greatly influence contractual responsibilities and construction activities as subcontractors generally execute 60 to 70 percent of the total project activity [1]. These subcontracting practices might vary depending on whether the project delivery method (PDM) and procurement policies selected allow for participants to be added to the project within a wide range of contractual options. Selecting the right subcontracting practice may promote the integration of the process deployed by contracting parties, increase reciprocal trust and achieve better project performance. Another possible improvement is the development of long-term associations between general contractors and subcontractors once they have contractually established the precise hierarchical structures for successful project performance.

Given these potential benefits, understanding the scope of emerging subcontracting practices is one way construction participants can try to improve project performance. To provide better information, this paper presents a brief synopsis of the findings from a U.S. nationwide survey and follow-up set of semi-structured interviews. The results are evaluated to identify the correlations between samples, to detect regional subcontracting patterns, and to identify potential new subcontracting practices.

Corresponding Author: Giovanni C. Migliaccio. Author email: gianciro@uw.edu 
Fernandez, Migliaccio, and Gebken / Proceedings of the Creative Construction Conference (2019) 043 https://doi.org/10.3311/CCC2019-043

\section{Subcontracting practices}

This research expands upon a previous study that identified and evaluated subcontracting practices in the state of Washington [2]. The previous study identified five different subcontracting practices. Figure 1 shows the following five subcontracting models found by Osmanbhoy: 1) traditional subcontracting (TS); 2) traditional subcontracting with design assist (TS-DA); 3) design-build subcontracting (DBS); 4) integrated design-construction subcontracting (IDCS); 5) integrated specialty work subcontracting (ISWS).

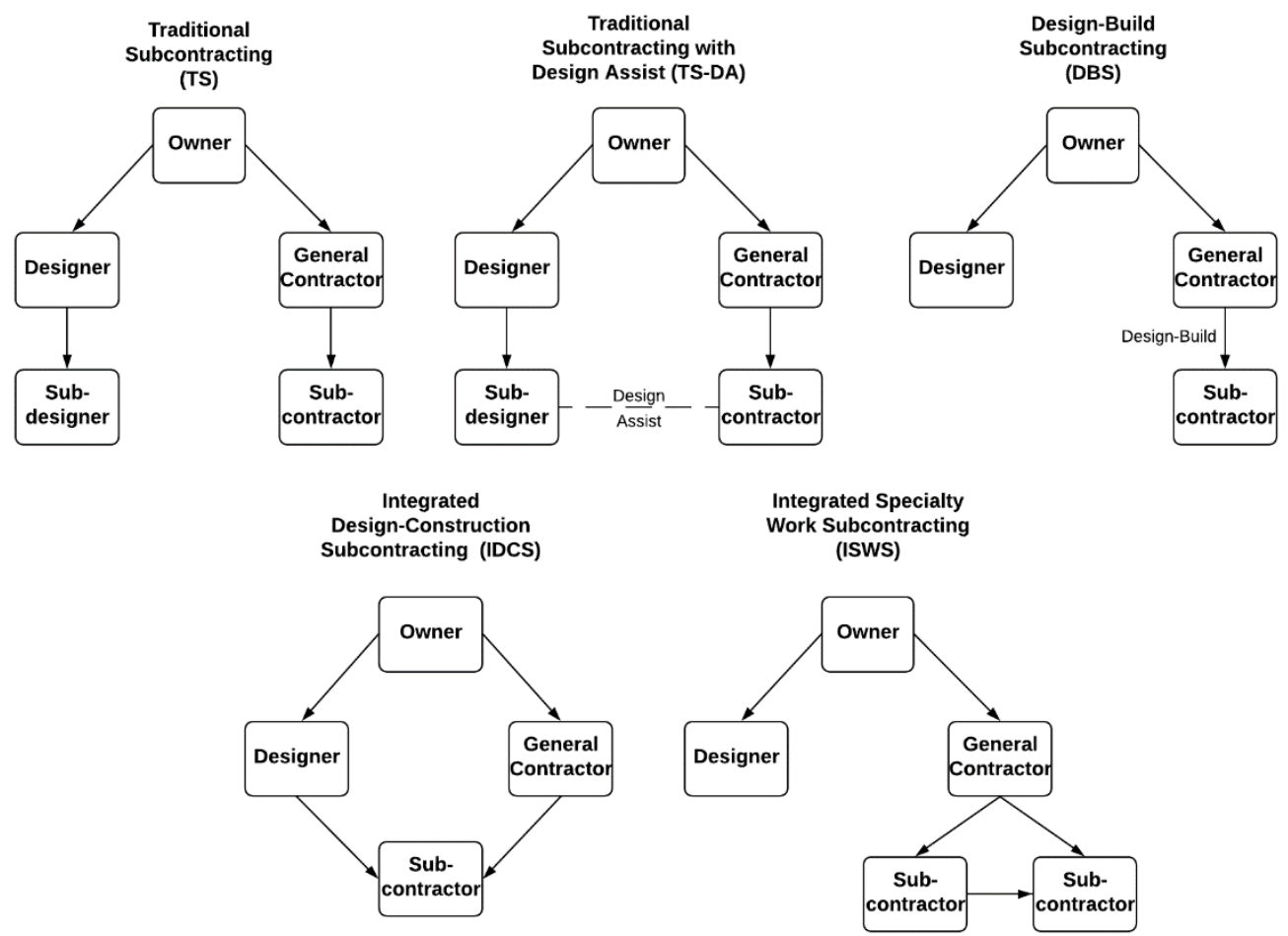

Fig. 1. Subcontracting practices.

\subsection{Traditional subcontracting (TS)}

This subcontracting practice is based on the segregation of design and construction activities into two separate supply and contracting chains. This practice generates two linear phases where the first phase is the development of drawings and specifications by the designer without the support of the contractor. Once these documents are used to secure prices from competing contractors, the second phase is focused on implementing construction activities [3,4]. As a result of these practices, the specialty expertise on each side (design and construction) work under isolated conditions where the direct link is their prime.

\subsection{Traditional subcontracting (TS-DA)}

Design-Assist practice mediates the segregation typical of TS by creating a path for collaboration between specialty designers and specialty contractors. This new collaboration path is described as the improvement of design and constructability concerns throughout the early involvement of specialty contractors in design activities. Although the specialty contractor is participating during the design process, this practice is not intended to transfer design liabilities to specialty contractors [5]. Under this collaborative design agenda, construction participants are expected to achieve better project results in cost, time, and quality. 
Fernandez, Migliaccio, and Gebken / Proceedings of the Creative Construction Conference (2019) 043 https://doi.org/10.3311/CCC2019-043

\subsection{Design-Build Subcontracting (DBS)}

Design-Build (DB) has been described extensively in the literature. However, DB has two different scenarios to involve specialty contractors during the project stages. The first scenario centers on the work of architects/engineers and general contractors; this joint-venture business association will design and provide the specification parameters to all specialty contractors to complete the design process together. This scenario sees the occurrence of DB integration at the prime contracting level and has been described in the literature. The second scenario focuses on the integration of DB principles at the subcontracting level and is novel; It relies on the selection of specialty contractors that will deliver both design and construction services within their specialty based on the specialty contractor's knowledge and solutions [6]. The last scenario resembles Osmanbhoy's DBS practice.

\subsection{Integrated Design-Construction Subcontracting (IDCS)}

The IDCS practice is one example of collaborative contracts and practices where the lead designer and general contractor have distinct contracts with the same specialty contractor who develops design documents and controls construction activities. IDCS practices have not been well-identified in the literature, but there are some insights which describe the potential links with this practice. For example, one case study details IDCS practices that were applied to a design-to-fabrication methodology for structural rebar using building information modeling (BIM) tools under a Construction Manager/General Contractor contractual strategy [7].

\subsection{Integrated Specialty Work Subcontracting (ISWS)}

The ISWS practice is focused on the development of collaborative methods to improve time and cost requirements. This development is created by all the specialty contractors using the detection of critical tasks that may quantify the correct amount of effort, participation, and resources in each construction activity for every subcontractor. This specialty contractor supportive agenda allows the existence of terms like reliability and contribution which generate revenue rewards that can be shared among team members [8].

\section{Research methodology}

A mixed methods approach was selected in order to provide a more nuanced view on subcontracting strategies and increase the generalizability of the results. The sample population for the study was obtained from multiple sources including the American Subcontractor Association (ASA), the Associated General Contractors of America (AGC), and from appropriate research team member contacts. A list of over 800 individuals was developed from these sources.

The first phase of data collection focused on obtaining information through an online survey instrument. The main goal of the survey was to establish contact with individuals in the dataset and to identify their key characteristics. The survey for both general and specialty contractors were both divided into two parts. The first part focused on obtaining general company information (i.e., type, size, market experience, and value), interviewee position, and professional contracting experience. The second part centered on gathering enough information to elucidate contractual approaches for each participant type.

In the second phase of data collection, semi-structured interviews were conducted. Based upon the response to whether or not respondents would like to be contacted for a follow-up telephone interview, the research team evaluated survey response data before selecting candidates. This allowed the research team to ensure interviewees would possess the required experience in and knowledge of subcontracting practices and models. The interviews were focused on obtaining all the insights from the participants related to the five key subcontracting practices, potential variations, and owner involvement. 
Fernandez, Migliaccio, and Gebken / Proceedings of the Creative Construction Conference (2019) 043 https://doi.org/10.3311/CCC2019-043

\section{Data collection and analysis}

\subsection{Online survey}

The survey was sent to 847 participants from 598 different companies; a total of 170 participants completed the survey representing a $20.07 \%$ participation rate. We excluded from the analysis seven survey response sets because they were incomplete. Tables 1, 2, and 3 show the survey top three answers from all the participants in three different sections: general information, general contractor, and specialty contractor segments. The online survey information was categorized following US Census Bureau Divisions.

\begin{tabular}{|c|c|c|c|}
\hline $\begin{array}{l}\text { Table 1. General information } \\
\text { segment. QUESTION }\end{array}$ & FIRST RESPONSE & SECOND RESPONSE & THIRD RESPONSE \\
\hline Location & West North Central (46\%) & West South Central (18\%) & South Atlantic (14\%) \\
\hline Participants' Experience & More than 15 years $(61 \%)$ & $\begin{array}{l}\text { Between } 5 \text { and } 15 \text { years } \\
(18 \%)\end{array}$ & Between 2 and 5 years $(13 \%)$ \\
\hline Participants' Position & Executive (51\%) & Project Manager (17\%) & Estimator/ Project Eng (13\%) \\
\hline Current Position Experience & From 0 to 5 years $(41 \%)$ & More than 15 years $(35 \%)$ & Between 5 and 15 years (23\%) \\
\hline Largest Contract Size & Between 1 and $10 \mathrm{M}(43 \%)$ & Between 10 and $50 \mathrm{M}(27 \%)$ & Between 50 and $250 \mathrm{M}(11 \%)$ \\
\hline Contractual Role & Prime Contractor $(61,37 \%)$ & Subcontractor $(102,63 \%)$ & N/A \\
\hline Participants' Involvement & Fully $(54 \%)$ & Somewhat $(38 \%)$ & Aware $(6 \%)$ \\
\hline Participants' Company Size & Between 10 and $50 \mathrm{M}(33 \%)$ & Less than $10 \mathrm{M}(21 \%)$ & Between 50 and $250 \mathrm{M}(17 \%)$ \\
\hline QUESTION & FIRST RESPONSE & SECOND RESPONSE & THIRD RESPONSE \\
\hline Adopted PDM ${ }^{M}$ & Design-Build (65\%) & Design-Bid-Build (63\%) & $\mathrm{CM}$ at Risk (62\%) \\
\hline Subcontracting Selection Criteria & Lowest Responsible Bid (85\%) & Best Qualifications (82\%) & Business Relationships (67\%) \\
\hline Multiple Contractual-Relationship & Yes $(57 \%)$ & No $(24 \%)$ & Unsure (19\%) \\
\hline Other Contractual Parties & Prime Contractor (70\%) & Owner/Client (49\%) & Designer (45\%) \\
\hline \multicolumn{4}{|l|}{ able 3. Specialty contractor segment. } \\
\hline Subcontractor Selection Criteria & Business Relationships (62\%) & Best Qualifications (5 & $\begin{array}{l}\text { Lowest Responsible Bid } \\
(51 \%)\end{array}$ \\
\hline Procurement Approach from $G C$ & Business Relationships (72\%) & $\begin{array}{l}\text { Lowest Responsible } \\
(71 \%)\end{array}$ & Best Qualifications (60\%) \\
\hline Contractual Bounded Parties & Prime Contractor (95\%) & Owner/Client (65\%) & $\begin{array}{l}\text { Specialty Contractor } \\
(39 \%)\end{array}$ \\
\hline Multiple Contractual-Relationship & Yes $(50 \%)$ & No $(47 \%)$ & Unsure $(3 \%)$ \\
\hline
\end{tabular}

\subsection{Follow-up interview}

Based on the selection participants criteria from the Research Methodology chapter, the expected response for the follow-up interviews was set at 36 interviews - 13 General Contractors and 23 Specialty Contractors. After three invitation cycles, 20 participants ( 13 General contractors and 7 Specialty Contractors) confirmed and completed the follow-up interview, resulting in a final response rate of 55.55 percent. Table 4 and 5 summarize all the key comments from the follow-up participants about the subcontracting practices, variations, and owner involvement.

The subcontracting models that have were explained to the participants were generally accepted and widely used by most participants. For this reason, the interviewees did not introduce any new subcontracting practices as expected in the research objectives. In contrast, the research identified small variations that can be used to augment existing models in several ways. These include four variations to Integrated Specialty Work Subcontracting strategy and modification to the Design-Build Subcontracting strategy. Table 4 indicates these modifications where all the secondary bullets are placed. Figure 2 graphically illustrates these five variations. 
Fernandez, Migliaccio, and Gebken / Proceedings of the Creative Construction Conference (2019) 043 https://doi.org/10.3311/CCC2019-043

Table 4. Follow-up interview subcontracting model and variations findings.

\begin{tabular}{|c|c|}
\hline SUBCONTRACTING MODEL & FINDINGS \\
\hline Traditional Subcontracting (TS) & $\begin{array}{ll}\text { - } & \text { Public Projects: } 80 \text { to } 100 \% \text { use } \\
\text { - } & \text { Private Projects: reduction from } 80 \text { to } 50 \% \text { use } \\
\text { - } & \text { Industry standard } \\
\text { - } & \text { Lack of involecontrol over SC } \\
\text { - } & \text { Low bid mentality }\end{array}$ \\
\hline $\begin{array}{l}\text { Traditional Subcontracting Design- } \\
\text { Assist (TS-DA) }\end{array}$ & $\begin{array}{ll}\text { - } & \text { It represents } 10 \text { to } 15 \% \text { use } \\
\text { - } & \text { Related to a pre-selected piece of equipment } \\
\text { - } & \text { Increase building coordination } \\
\text { - } & \text { Few SCs are capable of performing this method } \\
\text { - } & \text { Risk of shifting design liabilities to SC }\end{array}$ \\
\hline Design-Build Subcontracting (DBS) & $\begin{array}{ll}\text { - } & \text { It represents } 10 \text { to } 15 \% \text { use } \\
\text { - } & \text { Under traditional DB increases to } 30 \% \text { use } \\
\quad & \quad \text { o Lead designer inclusion in DB entity } \\
\text { - } & \text { SCs are fully committed to design process } \\
\text { - } & \text { Design flexibility to start construction faster } \\
\text { - } & \text { Better design and cost control } \\
\text { - } & \text { Design stage could be time-consuming }\end{array}$ \\
\hline $\begin{array}{l}\text { Integrated Design-Construction } \\
\text { Subcontracting (IDCS) }\end{array}$ & $\begin{array}{l}\text { - } \quad \text { Less than } 10 \% \text { use } \\
\text { - } \quad \text { Participants limited knowledge } \\
\text { - } \quad \text { Highly specialized products and early design associations among construction parties } \\
\text { - } \quad \text { Collusion and communication issues. }\end{array}$ \\
\hline $\begin{array}{l}\text { Integrated Specialty Work } \\
\text { Subcontracting (ISWS) }\end{array}$ & $\begin{array}{l}\text { - } \text { GCs have a } 50 \% \text { acceptance rate } \\
\text { - } \\
\text { - } \\
\text { - } \\
\text { - } \\
\text { Riss have a } 100 \% \text { acceptance rate } \\
\text { GCs develaying activities due to scope interference } \\
\circ \quad \text { Strict contractual arrangements } \\
\circ \quad \text { GC control over repetitive activities using specific specialty trades } \\
\text { - SCs develop solutions to execute specialized tasks } \\
\circ \quad \text { Inclusion to sub-subcontractors (third tiers) to one subcontractor } \\
\circ \quad \text { More than one link among subcontractors using sub-subcontractors }\end{array}$ \\
\hline
\end{tabular}

Table 5. Follow-up interview comments for IPD and owner involvement findings.

\begin{tabular}{|c|c|}
\hline SUBCONTRACTING MODEL & FINDINGS \\
\hline Integrated Project Delivery (IPD) & $\begin{array}{l}\text { - } \quad \text { IPD practices in Missouri and Colorado } \\
\text { - } \quad \text { Revenue based on sharing contingency of saving and losses } \\
\text { - } \quad \text { The revenue sharing is the incentive to improve coordination and collaboration } \\
\text { - } \quad \text { Successful IPD projects have the right combination of people } \\
\text { - Owners must keep the economic factor alive to make IPD projects attractive }\end{array}$ \\
\hline Owner Involvement & $\begin{array}{l}\text { - GCs have more opportunity to participate in the owner selection process of PDM and } \\
\text { procurement } \\
\text { - SCs could participate if owners select them early in the process } \\
\text { - Owners' request to be taught is the opportunity to create sophisticated owners who understand } \\
\text { the construction industry better }\end{array}$ \\
\hline
\end{tabular}

\section{Conclusions}

The ability to generalize the research finding to all regions of the U.S. is somewhat limited due to regional bias. Analysis of the online survey and follow-up interview data show that the majority of survey participants were from the West North-Central and West South-Central regions while interviews were generally concentrated in the central region of the United Stated. Nevertheless, the online survey and the follow-up interviews both exhibited a strong participant understanding of project delivery methods. In addition, research participants were adept at differentiating between various subcontracting strategies. However, within each PDM and procurement strategy, regional variations did exist. Divisional samples had some degree of equilibrium among traditional practices (i.e., DBB, lowest responsive bid, and no multi-contractual arrangements) and more collaborative techniques (e.g., DBB, CM/GC, business 
relationships, and best value), some regions were found to work with more traditional methods than others. Participants from the Pacific, Mountain, and West North Central divisions of the U.S. Census Bureau reported using more collaborative and multi-contractual practices. The other regions demonstrated a more equilibrated sample, with a tendency toward traditional methods. Given the regional bias, the research can infer two conclusions. First, all five subcontracting models studied to address the most common scenarios, and characteristics are familiar to the nationwide participant sample. Second, the need to find better contractual arrangements creates effective variations from the original models, and as such subcontracting practices are dynamic by nature.
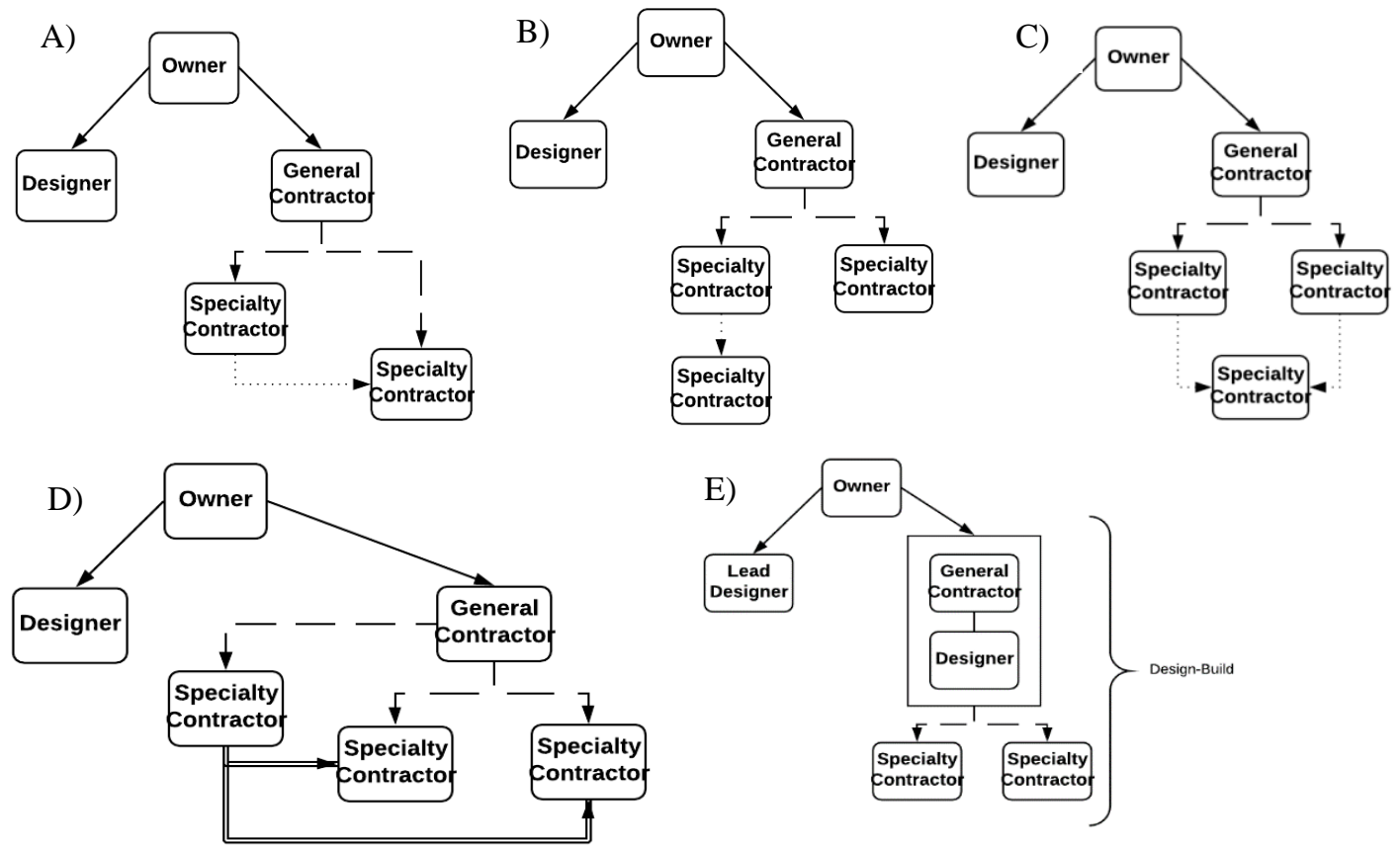

Fig. 2. A) ISWS variation 1; B) ISWS variation 2; C) ISWS variation 3; D) ISWS variation 4; E) DBS variation-confirmation 1.

\section{References}

[1] Maturana Sergio, Alarcón Luis Fernando, Gazmuri Pedro, and Vrsalovic Mladen. (2007). "On-Site Subcontractor Evaluation Method Based on Lean Principles and Partnering Practices." Journal of Management in Engineering, 23(2), 67-74. https://doi.org/10.1061/(ASCE)0742597X(2007)23:2(67)

[2] Osmanbhoy, N. M. A. (2015). "Closing the Contractual Circle: Investigating Emergent Subcontracting Approaches.” M. Sc., University of Washington, Seattle, WA. United States. https://doi.org/10.14288/1.0076435

[3] American Institute of Architects. (2007). "Integrated project delivery: a guide." 1, 1-62.

[4] American Institute of Architects and Associated General Contractors of America. (2011). "Primer on Project Delivery." 1-13.

[5] Arizona Board of Regents/Alliance for Construction Excellence. (2007). "Design Assist - Best Method Approach to Subcontracting." Alliance for Construction Excellence. 1-7.

[6] Gil, N., Tommelein, I. D., Kirkendall, R. L., and Ballard, G. (2001). Leveraging Specialty-Contractor Knowledge in Design-Build Organizations. 1-25. https://doi.org/10.1108/eb021196

[7] Javanmardi Ashtad, Abbasian-Hosseini S. Alireza, Liu Min, and Hsiang Simon M. (2018). "Benefit of Cooperation among Subcontractors in Performing High-Reliable Planning." Journal of Management in Engineering, 34(2), 04017062. https://doi.org/10.1061/(ASCE)ME.19435479.0000578

[8] Clevenger Caroline M., and Khan Ricardo. (2014). "Impact of BIM-Enabled Design-to-Fabrication on Building Delivery." Practice Periodical on Structural Design and Construction, 19(1), 122-128. https://doi.org/10.1061/(ASCE)SC.1943-5576.0000176 